\title{
Pengaruh Motivasi dan Disiplin Kerja Terhadap Kinerja Karyawan PT.Kahatex
}

\section{Ardi Nupi Hasyim}

Institut Manajemen Koperasi Indonesia

ardinupi@yahoo.com

\section{Germanus Ignasius Loyola Maje}

Institut Manajemen Koperasi Indonesia

lillomaje@gmail.com

\section{Vina ' Alimah}

Institut Manajemen Koperasi Indonesia vinaalimah@gmail.com

\section{Shintya Ayu Putri Priyadi}

Institut Manajemen Koperasi Indonesia chintasyp@gmail.com
Abstrack
The study aims to determine the effect of employee motivation on PT. Kahatex, the influence of employee work discipline at PT. Kahatex, as well as motivation and work discipline towards employees at PT. Kahatex. The data analysis method in this study uses the casual association method and uses a quantitative approach with quantitative data processing techniques with data processing techniques using multiple regression analysis. The data collection technique used was a questionnaire. Questionnaires distributed to employees of PT. Kahatex. Measurements were made with a Likert on a scale of one to five. The results of this study indicate that when viewed from a partial test $(t)$ it can be seen that the results of the tvalue (count) is 1,782<t(table) 2,042 or the Sig value of 0.085>0.05. it means that the motivation variable does not affect the performance of the employees of PT. Kahatex. Judging from the partial test $(t)$ can be known the results of the $t$ value (count) of $0.569<t$ (table) 2.042 or Sig value of 0.547>0.05. it means that the work discipline variable does not affect the performance of the employees of PT. Kahatex. While seen from the simultaneous test $(F)$ it can be seen that the significance value for motivation of Work Motivation (X1) and Work Discipline (X2) on Employee Performance $(Y)$ is $0,000<0.05$ and $F$ (count) 12,706> F (table) 3, 30, Undeniably As H3 is accepted which is intended as Work Motivation (X1) and Work Keywords Discipline (X2) simultaneously on Employee Performance (Y). Motivation, Work Discipline and Employee Performance 


\section{PENDAHULUAN}

Persaingan usaha saat ini mempunyai dampak yang penting bagi perkembangan usaha. Persaingan tersebut semakin ketat sehingga membuat perusahaan terus menciptakan inovasi-inovasi untuk memenangkan persaingan tersebut. Perusahaan akan berusaha untuk mencapai tujuan dengan efektif dan efisien. Hal itu dilakukan agar perusahaan mampu bersaing maupun mempunyai keunggulan dari pesaingnya. Keunggulan suatu perusahaan bisa dicapai harus memerlukan penanganan yang serius terhadap kinerja karyawan.

Pengelolaan sumber daya manusia yang harus matang harus dimulai dari awal karena nantinya akan sangat menentukkan kelangsungan organisasi. Hal ini menjadi tanggung jawab manajemen atau pemimpin organisasi, karena itu manajemen harus mampu membuat perencanaan yang matang, menyusun strategi yang efektif serta mampu mengkoordinasikan semua komponen perusahaan pada umumnya dan sumber daya pada khususnya (Sutrisno, 2009). Motivasi adalah sebuah faktor yang lebih mengarah pada perilaku dalam organisasi. Dalam diri seseorang selalu akan mempunyai motivasi yang digunakan untuk menggerakan perilakunya di dalam memenuhi tujuan tertentu. Motivasi karyawan dapat dipengaruhi oleh faktor minat, gaji yang diterima, kebutuhan akan rasa aman, hubungan antar personal dan kesempatan untuk bekerja. Adanya motivasi dapat merangsang karyawan untuk lebih menggerakan tenaga dan pikiran dalam merealisasikan tujuan perusahaan. Apabila kebutuhan akan hal ini terpenuhi maka timbul kepuasan dan kelancaran terhadap peningkatan kinerja karyawan. Dengan demikian dapat disimpulkan bahwa motivasi merupakan hal penting didalam meningkatkan kinerja karyawan adalah dengan memberikan motivasi, karena motivasi mampu untuk menggerakan semangat kerja dari karyawan yang nantinya dapat meningkatkan produktivitas kerja dan menjadikan suatu pekerjaan menjadi lebih sempurna.

Disiplin kerja mempunyai peranan yang sangat penting dalam pengembangan karir pada dasarnya sangatlah dibutuhkan bagi perusahaan swasta maupun pemerintahan dikarenakan pengembangan karir berorientasi pada tantangan bisnis di masa yang akan datang dalam menghadapi pesaing. Disiplin dalam bekerja juga sangat penting bagi karyawan sebuah perusahaan, karena itu kedisiplinan harus ditanamkan secara terus menerus kepada karyawan. Penanaman yang terus menerus menyebabkan disiplin tersebut menjadi kebiasaan bagi karyawan. Orang-orang yang berhasil dalam bidangnya masing masing, pada umumnya mempunyai tingkat kedisiplinan yang tinggi. Sebaliknya orang yang gagal, umumnya tidak disiplin. Sesungguhnya masalah kedisiplinan ini menjadi perhatian bagi setiap manusia.

Menurut Kiruja dan Elegwa (Kiruja, 2013) kinerja karyawan merupakan fungsi dari kemampuan dan motivasi, di mana kemampuan terdiri dari keterampilan, pelatihan dan sumber daya yang diperlukan untuk melakukan tugas dan motivasi digambarkan sebagai kekuatan batin yang mendorong individu untuk bertindak terhadap sesuatu. Peningkatan kinerja karyawan akan membawa kemajuan bagi perusahaan untuk dapat bertahan dalam suatu persaingan lingkungan bisnis yang tidak stabil. Oleh karena itu upaya-upaya untuk meningkatkan kinerja karyawan merupakan tantangan manajemen yang paling serius karena keberhasilan untuk mencapai tujuan dan kelangsungan hidup perusahaan tergantung pada kualitas kinerja sumber daya manusia yang ada didalamnya.

PT. Kahatex didirikan pada tahun 1979 oleh Mr LH Song. Perusahaan ini telah berkembang menjadi sebuah kompleks tekstil besar luas lebih dari dua lokasi manufaktur 
di Cijerah, Bandung dan Rancaekek dekat kota Bandung, dengan luas sekitar 150 hektar. Perusahaan mempunyai karyawan sebanyak 30.700, ini menempatkan perusahaan di jantung industri tekstil Indonesia. Saat ini perusahaan adalah pemasok utama untuk sektor tekstil Indonesia dan dinobatkan sebagai green Industri pertama di Indonesia dan memberikan kontribusi signifikan terhadap pasar ekspor.

Berdasarkan wawancara dengan manajer umum sumber daya manusia yang bernama Bapak Luddy pada bulan maret 2020. PT Kahatex diketahui bahwa berbicara kinerja sumber daya manusia di Indonesia masih jauh jika dibandingkan dengan kinerja sumber daya manusia di luar negeri baik dilihat dari sisi kedisplinan maupun penguasaan teknologi. Lingkungan perusahaan Kahatex berada dikabupaten Sumedang dan Bandung. Karyawan yang bekerja di Kahatex sendiri diketahui range pendidikannya merupakan sekolah menengah pertama dan sekolah menengah atas dan jarang melanjutkan ke dunia perkuliahan, sehingga persoalan tersebut yang menyebabkan perusahaaan tidak bisa bersaing dalam kecepatan produksinya walaupun sekarang perusahaan telah ditunjang dengan fasilitas teknologi yang bagus dan berstandar internasional. Perusahaan mempunyai karyawan mencapai puluhan ribu orang, karena sumber daya manusia yang kurang paham akan teknologi. Perusahaan mengalami penurunan pembelian tekstil oleh konsumen yang dimana saat ini penjualan tekstil sendiri kurang bagus. Perusahaan menjaga kelancaran proses produksi agar perusahaan dapat berkembang usahanya maka karyawan mempunyai tugas memproses dan mengolah input menjadi output, karyawan merupakan pemegang peranan penting dalam kelancaran proses produk dengan baik dan cekatan maka perlu mendapatkan perhatian serius, sehingga bisa menaikan peminat untuk membeli tekstil. Berkaitan dengan tugas tersebut penting bagi perusahaan untuk memotivasi para karyawan dan meningkatkan kedisplinan kerja yang masih perlu di perhatikan oleh perusahaan, diikuti dengan penegakan disiplin yang secara teratur maka akan tercipta kondisi yang tertib dan nyaman, dan juga dapat mengurangi penyimpangan yang dilakukan oleh karyawan perusahaan. Berdasarkan uraian diatas, penulis tertarik untuk mengambil judul penelitian mengenai "Pengaruh Motivasi dan Disiplin Kerja

\section{Terhadap Kinerja Karyawan pada PT.Kahatex"}

\section{LANDASAN TEORI}

\section{A. 1. Motivasi}

Motivasi adalah pemberian dorongan-dorongan individu untuk bertindak yang menyebabkan orang tersebut berperilaku dengan cara tertentu yang mengarah pada tujuan. Hasibuan (2003:219) mendefinisikan motivasi adalah pemberian daya penggerak yang menciptakan kegairahan kerja seseorang, agar mau bekerja sama, bekerja efektif dan terintegrasi dengan segala daya upayanya untuk mencapai kepuasan. Motivasi manusia yang telah dikembangkan oleh Maslow melalui penjelasan bahwa motivasi dipicu oleh usaha manusia untuk memenuhi kebutuhan (Mathis dan Jackson, 2001). Pada teori ini, Maslow mengklasifikasikan kebutuhan manusia yang diurutkan menjadi lima kategori. Hierarki kebutuhan Maslow terdiri atas :

a. Fisiologis, antara lain kebutuhan akan sandang, pangan, papan dan kebutuhan jasmani lain.

b. Keamanan, antara lain kebutuhan akan keselamatan dan perlindungan terhadap kerugian fisik dan emosional.

c. Sosial, antara lain kasih sayang, rasa saling memiliki, diterima-baik, persahabatan. 
d. Penghargaan, antara lain mencakup faktor penghormatan diri seperti harga diri, otonomi, dan prestasi; serta faktor penghormatan diri luar seperti misalnya status, pengakuan dan perhatian.

e. Aktualisasi Diri, merupakan dorongan untuk menjadi seseorang atau sesuai ambisinya yang mencakup pertumbuhan, pencapaian potensi, dan pemenuhan kebutuhan diri.

\section{Disiplin Kerja}

Seorang pemimpin ataupun seorang karyawan haruslah memiliki disiplin yang baik, karena disiplin yang baik merupakan cerminan dari rasa tanggung jawab yang dimiliki dalam melaksanakan tugas yang diberikan. Sastrohardiwiryo (2002:130) menyatakan Disiplin yaitu suatu sikap menghormati, menghargai, patuh dan taat terhadap peraturan-peraturan yang berlaku, baik yang tertulis maupun yang tidak tertulis serta sanggup menjalankannya dan tidak mengelak untuk menerima sanksi-sanksinya apabila ia melanggar tugas dan wewenang yang diberikan kepadanya. Menurut Hasibuan (2008:193) disiplinan adalah kesadaran dan kesediaan seseorang mentaati semua peraturan dan norma-norma sosial yang berlaku. Kesadaran adalah contoh sikap seseorang yang secara suka rela menaati semua peraturan dan sadar akan tugas dan tanggung jawabnya.

\section{Kinerja Karyawan}

Hasibuan (2007: 23) mengemukakan, bahwa kinerja hakikatnya suatu hasil kerja yang dapat dicapai oleh seseorang atau kelompok orang dalam suatu organisasi, sesuai dengan wewenang dan tanggung jawab masing-masing dalam rangka mencapai tujuan organisasi secara legal, tidak melanggar hukum dan sesuai dengan moral dan etika. Mangkunegara (2012:9) mengungkapkan kinerja karyawan adalah hasil kerja secara kualitas dan kuantitas yang dicapai oleh seseorang karyawan dalam melaksanakan tugasnya sesuai dengan tanggung jawab yang diberikan kepadanya. Wibowo (2010:7) Manajemen kinerja memfokuskan pada apa yang diperlukan oleh organisasi, manajer, dan pekerja untuk berhasil. Pengukuran kinerja harus mempunyai standart yang baik karena pengukuran kinerja adalah alat untuk mengukur pencapaian tujuan dan sasaran sebagai acuan pengambilan keputusan.

\section{METODOLOGI PENELITIAN Rancangan Penelitian}

Penelitian ini dilakukan di PT. Kahatex yang beralamat di Jl. Raya Rancaekek KM 23/25 Rancaekek, Kab. Bandung, Jawa Barat 40394. Metode pengumpulan data yang digunakan adalah metode kuesioner dan wawancara. Dalam menganalisis data penulis menggunakan metode asosiasi kausal serta menggunakan pendekatan kuantitatif. Metode asosiasi kausal adalah penelitian yang digunakan untuk membuktikan sejauh mana hubungan antara dua variabel atau lebih. Hubungan kausal adalah hubungan yang bersifat sebab akibat. Dalam penelitian ini terdapat variabel independent (yang mempengaruhi) dan dependent (yang dipengaruhi). Menurut Sugiyono (2016:21) metode asosiatif merupakan penelitian yang bertujuan untuk mengetahui pengaruh ataupun hubungan antara dua variabel atau lebih. Sedangkan pendekatan kuantitatif adalah pendekatan dimana data yang diperoleh berupa angka dan dianalisis sesuai dengan metode statistik 
yang digunakan. Penelitian ini akan menjelaskan pengaruh motivasi dan disiplin kerja terhadap kinerja karyawan.

\section{Metode Penentuan Populasi dan Sampel \\ Populasi}

Populasi adalah wilayah generalisasi yang terdiri atas objek atau subjek yang memiliki kualitas dan karakteristik tertentu yang ditetapkan oleh peneliti untuk dipelajari lalu ditarik kesimpulannya (Sugiyono, 2008:61). Populasi dari penelitian ini adalah karyawan bagian SDM yang ada di PT Kahatex yang berjumlah 206 orang.

\section{Sampel}

Menurut Sugiyono (2016:116) sampel adalah bagian dari jumlah dan karakteristik yang dimiliki oleh populasi tersebut. Dengan demikian sampel adalah sebagian dari populasi yang karakteristiknya hendak diselidiki, dan bisa mewakili keseluruhan populasinya sehingga jumlahnya lebih sedikit dari populasi. Karena populasi dalam penelitian ini diketahui maka dalam pengambilan jumlah sampel penulis menggunakan Slovin :

Keterangan :

$$
n=\frac{N}{1+N(e)^{2}}
$$

$\mathrm{n}=$ ukuran sampel

$\mathrm{N}=$ ukuran populasi

$\mathrm{e}=$ persen kelonggaran ketidaktelitian karena kesalahan pengambilan sampel yang masih dapat ditolerir

Dalam rumus Slovin ada ketentuan sebagai berikut:

Nilai e $=0,1(10 \%)$ untuk populasi dalam jumlah besar

Nilai e $=0,2(20 \%)$ untuk populasi dalam jumlah kecil

Jadi rentang sampel yang dapat diambil dari teknik Solvin adalah antara 10-20\% dari populasi penelitian. Jumlah populasi dalam penelitian ini adalah sebanyak 206 karyawan, sehingga presentase kelonggaran yang digunakan adalah $16 \%$ dan hasil perhitungan dapat dibulatkan untuk mencapai kesesuaian. Maka untuk mengetahui sampel penelitian, dengan perhitungan sebagai berikut:

$$
\begin{aligned}
n= & \frac{206}{1+206(0,16)^{2}} \\
& =32,83 \text { responden } \\
& \approx 33 \text { responden }
\end{aligned}
$$

Dengan demikian sampel yang akan dilibatkan dalam penelitian ini adalah karyawan bagian SDM PT Kahatex yang berjumlah 33 responden.

\section{Teknik Analisis Data}

\section{Uji Validitas dan Uji Reliabilitas}

Uji validitas menunjukkan sejauh mana suatu alat ukur itu dapat mengukur variabel yang akan diukur. Suatu instrumen dikatakan valid jika instrumen ini mampu mengukur apa saja yang hendak diukurnya, mampu mengungkapkan apa yang ingin diungkapkan. 
Menurut Kuncoro (2003:154), "Reliabilitas menunjukan konsistensi dan stabilitas dari suatu skor (skala pengukuran). Kriteria dalam pengukuran ini adalah jika cronbach alphanya memiliki nilai $\geq 0,6$ maka data dikatakan reliabel.

\section{Model Regresi Linier Berganda}

Model regresi ini menggunakan metode analisis regresi linier berganda digunakan dalam penelitian ini untuk mempelajari dependen dalam suatu fenomena. Menurut Priyono (2015:15), analisis linier regresi berganda adalah menganalisis hubungan secara linier antara dua variabel atau lebih variabel independen $(\mathrm{X} 1, \mathrm{X} 2, \mathrm{X} 3, \ldots \mathrm{Xn})$ dengan variabel dependen (Y). formulasi persamaan regresi linier berganda adalah sebagai berikut :

Keterangan :

$$
Y=a+\beta 1 . X 1+\beta 2 . X 2+e
$$

$\mathrm{Y}=$ Kinerja Karyawan

$\mathrm{a}=$ konstanta (nilai $\mathrm{Y}$ apabila $\mathrm{X} 1, \mathrm{X} 2, \ldots . \mathrm{Xn}=0$ )

$\beta 1, \beta 2, \ldots . \beta n=$ Koefisien Regresi

$\mathrm{X} 1=$ Motivasi

$\mathrm{X} 2$ = Disiplin Kerja

\section{Uji Asumsi Klasik}

\section{Uji Normalitas}

Uji normalitas ini digunakan untuk mengetahui apakah data berdistribusi normalatau tidak dapat menggunakan uji Kolmogorov-Smirnov. Jika signifikansi atau nilai probabilitas $>$ dari $\alpha=0,05$, maka data tersebut berdistribusi normal. Dan sebaliknya jika nilai probabilitasnya $<$ dari $\alpha=0,05$, maka data tidak berdistribusi normal. Uji asumsi normalitas yang lebih kompleks dan lengkap sering juga disebut dengan uji kesesuaian model (goodness of fit (GOF)) dimaksudkan untuk menguji apakah model yang diusulkan memiliki kesesuaian (fit) dengan data atau tidak.

\section{Uji Heteroskedastisitas}

Heteroskedastisitas merupakan salah satu faktor yang menyebabkan model regresi linear tidak efisien dan akurat, juga mengakibatkan penggunaan metode kemungkinan maksimum dalam mengestimasi parameter (koefisien regresi akan terganggu).

\section{Uji Multikolinearitas}

Uji multikolinieritas dilakukan untuk mengetahui apakah antar variabel bebas dalam persamaan regresi tersebut tidak saling berkorelasi. Untuk mendeteksi Multikolinearitas adalah dengan melihat nilai tolerance (TOL) dan nilai variance inflation faktor (VIF), dimana menurut Hair et al dalam duwi priyanto (2009) variabel dikatakan mempunyai masalah multikolinearitas apabila nilai tolerance lebih kecil dari 0,1 atau nilai VIF lebih besar dari 10 .

\section{Pengujian Hipotesis}

\section{Uji Parsial (t)}

Uji t digunakan untuk menguji signifikansi hubungan antara variabel $\mathrm{X}$ dan variabel $\mathrm{Y}$ secara parsial atau dapat dikatakan uji t pada dasarnya menunjukan seberapa jauh satu variabel independen secara individual dalam menerangkan variasi-variasi dependen 
(Ghozali,2012). Digunakan untuk menguji kebenaran hipotesis dan pengaruh variabel independen secara parsial terhadap variabel dependen. Dapat dilihat dengan langkahlangkah sebagai berikut :

a) $\quad \alpha=0,05$

b) $\quad \mathrm{t}$ uji $=\frac{\beta}{s_{b}}$

Dimana :

$\mathrm{b}=$ koefisien

$\beta=$ Koefisien regresi

$\mathrm{Sb}=$ Standar eror koefisien regresi

Jika nilai signifikan p-value, $\alpha \leq 0,05$, maka H0 ditolak dan $\mathrm{H} 1$ di terima. Dan jika nilai tidak signifikan p-value, $\alpha \geq 0,05$, maka $\mathrm{H} 0$ diterima dan $\mathrm{H} 1$ ditolak.

\section{Uji Simultan (F)}

Uji F pada dasarnya menunjukkan apakah semua variabel bebas yang dimasukkan dalam model mempunyai pengaruh secara bersama-sama terhadap variabel terikat, (Ghozali, 2012). Uji F Digunakan untuk menguji kebenaran hipotesis dengan membuktikan keberadaan pengaruh yang berarti dari variabel-variabel bebas secara keseluruhan terhadap variabel terikat dalam sebuah analisis atau untuk melihat signifikansi secara statistik pengaruh variabel independen secara serentak terhadap variabel dependen pengujian sebagai berikut :

a) $\quad \alpha=0.05$

b) $\quad$ Fuji $=\frac{\frac{R^{2}}{K}}{\frac{\left(1-R^{2}\right.}{n-K-1}}$

\section{Dimana :}

$\mathrm{R} 2=$ Koefisien determinasi

$\mathrm{K}=$ Jumlah variabel independen

$\mathrm{N}=$ Jumlah sampel

$\mathrm{F}=$ Nilai F hitung

Jika nilai signifikan $\mathrm{F}<0,05$, maka $\mathrm{H} 0$ ditolak dan $\mathrm{H} 1$ diterima. Dan nilai signifikan $\mathrm{F}$ $>0,05$, maka H0 diterima dan ditolak.

\section{HASIL PENELITIAN}

\section{Uji Validitas dan Uji Reliabilitas}

Uji Validitas digunakan untuk mengetahui kevalidan kuisioner dalam mengumpulkan data. Uji validitas dilakukan dengan rumus korelasi bivariate person dengan alat bantu program SPSS versi 22. Item kuisioner dalam uji validitas dikatakan valid jika harga $r_{\text {hitung }}>r_{\text {tabel }}$ pada nilai signifikansi 5\%. Sebaliknya, item dikatakan tidak valid jika $r_{\text {hitung }}<r_{\text {tabel }}$ pada nilai signifikansi $5 \%$ atau juga bisa. Adapun hasil uji validitas (kuesioner) yang telah dilakukan ternyata sebanyak 17 butir pertanyaan untuk variabel motivasi (X1) dinyatakan valid dan 10 butir pertanyaan untuk variabel disiplin kerja (X2) juga dinyatakan valid. Sedangkan 1 dari 10 butir pertanyaan untuk variabel kinerja karyawan (Y) dinyatakan tidak valid dan tersisa 9 butir pertanyaan untuk variabel kinerja karyawan (Y) dinyatakan valid. Sehingga tahapan uji reliabilitas dapat dilanjutkan untuk semua butir kuesioner yang valid tersebut. 
Dari uji realibilitas yang dilakukan dengan menggunakan rumus alpha. Uji signifikansi dilakukan pada taraf nyata $5 \%(\alpha=0,05)$. Nilai koefisien reliabilitas pada variabel Motivasi Kerja sebesar 0.912, variabel Disiplin Kerja sebesar 0,890, dan variabel Kinerja Karyawan sebesar 0,886. Disesuaikan dengan kriteria uji Guilford, nilai diatas lebih besar dari 0.8 maka hasil kuesioner memiliki tingkat reliabilitas yang sangat tinggi atau dengan kata lain hasilnya sangat bisa.

\section{Analisis Regresi Berganda}

\section{Perumusan Hipotesis}

- $H_{1}=$ Terdapat pengaruh Motivasi Kerja (X1) terhadap Kinerja Karyawan (Y)

- $H_{2}=$ Terdapat pengaruh Dispilin Kerja (X1) terhadap Kinerja Karyawan (Y)

- $H_{3}=$ Terdapat pengaruh Motivasi Kerja (X1) dan Dispilin Kerja (X2) secara simultan terhadap Kinerja Karyawan (Y)

- Derajat Kepercayaan 95\% ( $(=0,95), \alpha=0,05$

\section{Dasar Pengambilan Keputusan}

\section{a) $\mathbf{U j i} \mathbf{t}$}

- Jika nilai Sig. < 0,05, atau thitung > t table maka terdapat pengaruh variabel bebas (X) terhadap variabel terikat (Y)

- Jika nilai Sig. $>0,05$, atau $\mathrm{t}$ hitung $<\mathrm{t}$ table maka tidak terdapat pengaruh variabel bebas $(\mathrm{X})$ terhadap variabel terikat $(\mathrm{Y})$

\section{b) Uji F}

$$
\mathrm{t} \text { table }=\mathrm{t}(\alpha / 2 ; \mathrm{n}-\mathrm{k}-1)=\mathrm{t}(0,025 ; 30)=2,042
$$

- Jika nilai Sig. < 0,05, atau F hitung > F tabel maka terdapat pengaruh variabel bebas $(\mathrm{X})$ secara simultan terhadap variabel terikat $(\mathrm{Y})$

- Jika nilai Sig. $>0,05$, atau $\mathrm{F}$ hitung $<\mathrm{F}$ tabel maka tidak terdapat pengaruh variabel bebas $(\mathrm{X})$ secara simultan terhadap variabel terikat $(\mathrm{Y})$

$$
\text { F tabel }=\text { F }(k ; n-k)=F(2 ; 31)=3,30
$$

\section{Tabel 1 Pengujian Hipotesis H1 dan $\mathrm{H} 2$ dengan U.ji t}

$$
\text { Coefficients }^{a}
$$

\begin{tabular}{|ll|r|r|r|r|r|}
\hline \multirow{2}{*}{ Model } & \multicolumn{2}{|c|}{ Unstandardized Coefficients } & \multicolumn{2}{c|}{$\begin{array}{c}\text { Standardized } \\
\text { Coefficients }\end{array}$} & \\
\cline { 2 - 4 } & \multicolumn{1}{|c|}{$\mathrm{B}$} & \multicolumn{1}{c|}{ Std. Error } & \multicolumn{1}{c|}{ Beta } & \multicolumn{1}{c|}{ Sig. } \\
\hline 1 & (Constant) & 7.398 & 4.163 & & 1.777 & .086 \\
& Motivasi Kerja $(\mathrm{X} 1)$ & .347 & .195 & .524 & 1.782 & .085 \\
& Disiplin Kerja $(\mathrm{X} 2)$ & .166 & .291 & .167 & .569 & .574 \\
\hline
\end{tabular}

a. Dependent Variable: Kinerja Karyawan $(Y)$

\section{Pengujian Hipotesis Pertama (H1)}

Diketahui nilai Sig. untuk pengaruh Motivasi Kerja (X1) terhadap Kinerja Karyawan (Y) adalah sebesar 0,085 > 0,05 dan nilai t hitung 1,782 < t tabel 2,042, sehingga dapat disimpulkan bahwa $\mathrm{H} 1$ ditolak yang berarti tidak terdapat pengaruh Motivasi Kerja (X1) terhadap Kinerja Karyawan (Y). 


\section{Pengujian Hipotesis Pertama (H2)}

Diketahui nilai Sig. untuk pengaruh Disiplin Kerja (X1) terhadap Kinerja Karyawan (Y) adalah sebesar 0,547>0,05 dan nilai t hitung 0,569 < t tabel 2,042, sehingga dapat disimpulkan bahwa H2 ditolak yang berarti tidak terdapat pengaruh Displin Kerja (X2) terhadap Kinerja Karyawan (Y).

\section{Pengujian Hipotesis H3 dengan Uji F}

Berdasarkan output di atas diketahui bahwa nilai signifikansi untuk pengaruh Motivasi Kerja (X1) dan Disiplin Kerja (X2) terhadap Kinerja Karyawan (Y) adalah sebesar 0,000 $<0,05$ dan nilai $\mathrm{F}$ hitung 12,706 > F tabel 3,30.

\section{Tabel 2 Uji F}

ANOVA $^{\mathrm{a}}$

\begin{tabular}{|ll|r|r|r|r|r|}
\hline \multicolumn{1}{|c|}{} & \multicolumn{1}{c|}{$\begin{array}{c}\text { Sum of } \\
\text { Squares }\end{array}$} & df & Mean Square & F & Sig. \\
\hline 1 & Regression & 567.454 & 2 & 283.727 & 12.706 & $.000^{\text {b }}$ \\
& Residual & 669.879 & 30 & 22.329 & & \\
& Total & 1237.333 & 32 & & & \\
\hline
\end{tabular}

a. Dependent Variable: Kinerja Karyawan ( $)$

b. Predictors: (Constant), Disiplin Kerja ( $\times 2$ ), Motivasi Kerja ( $\times 1$ )

Berdasarkan output di atas diketahui bahwa nilai signifikansi untuk pengaruh Motivasi Kerja (X1) dan Disiplin Kerja (X2) terhadap Kinerja Karyawan (Y) adalah sebesar 0,000 $<0,05$ dan nilai $\mathrm{F}$ hitung 12,706 > F tabel 3,30, sehingga dapat disimpulkan bahwa H3 diterima yang berarti terdapat pengaruh Motivasi Kerja (X1) dan Disiplin Kerja (X2) secara simultan terhadap Kinerja Karyawan (Y).

\section{Tabel 3 Koefisien Determinasi}

Model Summary

\begin{tabular}{|l|l|r|r|r|}
\hline Model & $\mathrm{R}$ & R Square & $\begin{array}{c}\text { Adjusted R } \\
\text { Square }\end{array}$ & $\begin{array}{c}\text { Std. Error of } \\
\text { the Estimate }\end{array}$ \\
\hline 1 & $.677^{\mathrm{a}}$ & .459 & .423 & 4.725 \\
\hline
\end{tabular}

a. Predictors: (Constant), Disiplin Kerja (X2), Motivasi Kerja (X1)

Berdasarkan output diatas diketahui nilai R Square 0,459, hal ini mengandung arti bahwa pengaruh variabel X1 dan X2 secara simultan terhadap variabel Y adalah sebesar 45,90 $\%$, sedangkan sisanya $54,10 \%$ dijelaskan atau dipengaruhi oleh variabel lain.

\section{Uji Asumsi Klasik}

\section{Uji Normalitas}

- Suatu data dapat dikatakan normal jika P-Level(Asymp.Sig. (2-tailed)) lebih dari 0,05 $(\alpha)$

- Pada data diatas, nilai $P$-Level $=0,200$. Jika dibandingkan dengan 0,05 $(\alpha)$ maka $P$ level $(0,200)>\alpha(0,05)$ 
Simpulan : Berdasarkan hasil analisis tersebut, data yang sudah dianalisis dapat dikatakan data berdistribusi normal.

\section{Uji Hetereoskedastisitas}

Berdasarkan hasil yang diperoleh, variable motivasi kerja memiliki nilai sig. 0,970 dan Variabel disiplin kerja (X2) 0,885 . Jika dibandingkan dengan nilai alpha $(0,05)$ maka nilai dari variable independen tersebut lebih besar dari alpha. Atas dasar hal tersebut, kedua variable bebas yang diteliti tidak terjadi masalah heteroskedastisitas

\section{Uji Multikolinearitas}

Berdasarkan hasil yang diperoleh dapat disimpulkan bahwa model regresi pengaruh antara variabel motivasi kerja dan disiplin kerja apabila dilihat dari nilai tolerance sebesar 0,229 ataupun VIF sebesar 4,372 tidak terjadi gejala multikolinearitas. Maka uji ini bisa dilakukan dalam penelitian ini.

\section{PEMBAHASAN}

Hasil dalam penelitian ini menunjukan bahwa hasil dari variabel motivasi kerja (X1) tidak berpengaruh parsial terhadap varaibel kinerja karyawan. Hasil dalam penelitian ini sejalan dengan penelitian yang dilakukan oleh Ida (2016), yang meneliti Pengaruh Motivasi dan Disiplin Kerja Terhadap Kinerja Karyawan Dibagian Produksi pada PT. Gatra Mapan Ngijo Karangploso membuktikan bahwa motivasi tidak berpengaruh parsial terhadap kinerja karyawan PT. Gatra Mapan Ngijo Karangploso. Ada juga variabel disiplin kerja (X2) tidak berpengaruh parsial terhadap variabel kinerja karyawan. Hasil dalam penelitian ini tidak sejalan dengan penelitian yang dilakukan oleh Ida (2016), yang meneliti Pengaruh Motivasi dan Disiplin Kerja Terhadap Kinerja Karyawan Dibagian Produksi pada PT. Gatra Mapan Ngijo Karangploso membuktikan bahwa disiplin kerja berpengaruh parsial terhadap kinerja karyawan PT. Gatra Mapan Ngijo Karangploso. Namun pada penelitian menunjukkan bahwa motivasi dan disiplin kerja berpengaruh signifikan terhadap kinerja karyawan dilakukan secara bersama-sama atau secara simultan. Hal tersebut berarti apabila motivasi dan disiplin kerja diberikan kepada karyawan perusahaan PT.Kahatex secara bersamaan maka kinerja karyawan akan memajukan dan mempertahankan perusahaan dalam suatu persaingan lingkungan bisnis yang tidak stabil. Hal ini diperkuat dan didukung oleh hasil uji $\mathrm{f}$ yang menghasilkan

$F_{\text {hitung }} 12,706>F_{\text {tabel }} 3,30$ yang artinya hubungan motivasi dan displin kerja terhadap kinerja karyawan berpengaruh signifikan. Hasil dalam penelitian ini sejalan dengan penelitian yang dilakukan oleh Ida (2016), yang meneliti Pengaruh Motivasi dan Disiplin Kerja Terhadap Kinerja Karyawan Dibagian Produksi pada PT. Gatra Mapan Ngijo Karangploso membuktikan bahwa motivasi dan disiplinkerja berpengaruh simultan terhadap kinerja karyawan PT. Gatra Mapan Ngijo Karangploso.

\section{KESIMPULAN}

Berdasarkan hasil penelitian dan analisis yang telah dilakukan kepada karyawan PT. Kahatex tentang pengaruh Motivasi dan Disiplin Kerja terhadap Kinerja Karyawan maka dapat disimpulkan bahwa jika menggunakan uji secara parsial, atau tidak dibaurkan maka variabel motivasi kerja dan variabel disiplin kerja tidak berpengaruh terhadap kinerja karyawan hal ini bisa dilihat bahwa nilai $t_{\text {hitung }}$ lebih kecil dari nilai $t_{\text {tabel }}$ dan 
nilai Sig lebih besar dari 0,05. Sedangkan jika menggunakan uji secara simultan atau dilakukakn secara bersama-sama maka variabel motivasi kerja dan variabel disiplin kerja berpengaruh signifikan terhadap kinerja karyawan hal ini bisa dilihat bahwa nilai $F_{\text {hitung }}$ lebih besar dari nilai $F_{\text {tabel }}$.

\section{DAFTAR PUSTAKA}

Hanafi, B. D., \& Yohana, C. (2017). PENGARUH MOTIVASI, DAN LINGKUNGAN KERJA, TERHADAP KINERJA KARYAWAN, DENGAN KEPUASAN KERJA SEBAGAI VARIABEL MEDIASI PADA PT BNI LIFEINSURANCE. Jurnal Pendidikan Ekonomi Dan Bisnis (JPEB). https://doi.org/10.21009/jpeb.005.1.6

Hartaroe, B. P., Mardani, R. M., \& Abs, M. K. (2016). Prodi manajemen. 82-94.

Hidayat, R. (2019). Pengaruh Debt To Asset Ratio (Dar) Dan Receivable Turn Over (Rto) Terhadap Return On Equity (Roe) Pada Pt. Perkebunan Nusantara Ii Tanjung Morawa. Prosiding Seminar Nasional Era Industri (SNEI) 4.0.

Ivonne A. S. Sajangbati. (2013). MOTIVASI, DISIPLIN, DAN KEPUASAN PENGARUHNYA TERHADAP KINERJA PEGAWAI PT. POS INDONESIA (PERSERO) CABANG BITUNG. Jurnal Riset Ekonomi, Manajemen, Bisnis Dan Akuntansi.

Josep, W., AR, M., \& Azizah, D. (2016). PENGARUH UKURAN PERUSAHAAN, RETURN ON ASSET DAN NET PROFIT MARGIN TERHADAP PERATAAN LABA (INCOME SMOOTHING) (Studi pada Perusahaan Manufaktur yang Terdaftar di BEI 2012-2014). Jurnal Administrasi Bisnis S1 Universitas Brawijaya.

Mananeke, L., Mandey, S., \& Katiandagho, C. (2014). PENGARUH DISIPLIN KERJA KEPEMIMPINAN DAN MOTIVASI TERHADAP KINERJA PEGAWAI PADA PT. PLN (PERSERO) WILAYAH SULUTTENGGO AREA MANADO. Jurnal Riset Ekonomi, Manajemen, Bisnis Dan Akuntansi. https://doi.org/10.35794/emba.v2i3.5919

Mandey, S., \& Sahangggamu, P. (2014). PENGARUH PELATIHAN KERJA, MOTIVASI, DAN DISIPLIN KERJA TERHADAP KINERJA KARYAWAN PADA PT. BANK PERKREDITAN RAKYAT DANA RAYA. Jurnal Riset Ekonomi, Manajemen, Bisnis Dan Akuntansi. https://doi.org/10.35794/emba.v2i4.6359

Manoppo, R. (2015). PENGARUH DISPLIN KERJA, MOTIVASI KERJADAN PENGEMBANGAN KARIR TERHADAP KEPUASAN KERJA PADA TVRI SULAWESI UTARA. Jurnal Riset Ekonomi, Manajemen, Bisnis Dan Akuntansi. 
Murti, H., \& Srimulyani, V. A. (2013). Pengaruh Motivasi Terhadap Kinerja Pegawai Dengan Variabel Pemediasi Kepuasaan Kerja Pada Pdam Kota Madiun. JRMA Jurnal Riset Manajemen Dan Akuntansi.

Reza, R. A. (2010). Pengaruh Gaya Kepemimpinan, Motivasi dan Disiplin Kerja Terhadap Kinerja Karyawan PT Sinar Santosa Perkasa Banjarnegara. Pengaruh Gaya Kepimpinan, Motivasi Dan Disiplin Kerja Terhadap Kinerja Karyawan Pt Sinar Santosa Perkasa Banjarnegara.

Salkind, N. (2012). Random Sampling. Encyclopedia of Research Design, 42-57. https://doi.org/10.4135/9781412961288.n364

Sendow, G., Mekel, P., \& Tindow, M. I. (2014). DISIPLIN KERJA, MOTIVASI DAN KOMPENSASI PENGARUHNYA TERHADAP KINERJA KARYAWAN PADA PT. BANK SULUT CABANG CALACA. Jurnal Riset Ekonomi, Manajemen, Bisnis Dan Akuntansi.

Sidanti, H. (2015). Pengaruh lingkungan kerja, disiplin kerja dan motivasi kerja terhadap kinerja pegawai negeri sipil di sekretariat dprd kabupaten madiun. Jurnal JIBEKA.

Sitohang, I. S. \& S. (2017). Pengaruh Motivasi, Kompensasi, Kesehatan dan Keselamatan Krja Terhadap Kinerja Karyawan Imanuel Dwi Santoso. Jrnal Illmu Dan Riset Manajemen.

Sudarwati, S. (2014). PENGARUH MOTIVASI, DISIPLIN KERJA DAN KOMPETENSI TERHADAP KINERJA PEGAWAI DINAS PENDIDIKAN KABUPATEN SRAGEN. Jurnal Paradigma Universitas Islam Batik Surakarta.

Worang, A., \& Runtuwene, R. F. (2019). Pengaruh Motivasi Dan Disiplin Kerja Terhadap Kinerja Karyawan PDAM Kota Tomohon. Jurnal Administrasi Bisnis, 8(2), 10. https://doi.org/10.35797/jab.8.2.2019.23509.10-16 